\title{
How to Interpret Galdós's Tormento? What the Galley Proofs Tell Us.
}

A lo largo de los últimos sesenta años los críticos de Galdós han mantenido una discusión sobre cómo interpretar la novela Tormento. Por un lado, algunos estudiosos han sostenido que ésta narra la historia de una mujer perspicaz, seductora y egoísta que consigue hacerse de forma deshonesta con un marido riquísimo pero ingenuo. Por otro lado, hay estudiosos de la novela que han argumentado que su protagonista, Amparo Sánchez Calderón, es la víctima de una sociedad cruel e injusta que logra salvarse milagrosamente de un futuro empobrecido. Hasta la fecha y pese a la existencia de varias ediciones críticas de Tormento no se han mirado las pruebas de imprenta de la novela para determinar si ofrecen pruebas a favor o en contra de una interpretación u otra. Por lo tanto, en este trabajo se argumenta que los cambios que el propio autor incorporó a su texto a la hora de corregir las pruebas de imprenta demuestran de forma significativa que Galdós no veía en su protagonista a una mujer interesada e inmoral, sino todo lo contrario.

Over the last sixty years students of Galdós might have been forgiven for wondering whether there were not two wildly contrasting versions of Tormento (1884) in print. For much of that time, critics of the work have lined up on either side of a polarized debate, producing conflicting accounts of its characterization, attitudes to women, and overall meaning. While some have contended that it exposes the machinations of a scheming and dishonest young woman in her plot to ensnare a wealthy husband, others would have it that Galdós used his novel to explore the moral and social vulnerability of the female working classes. Absent from that debate until now has been a detailed examination of the changes Galdós made to his text at the proof stage and what they tell us about how to construe a novel that appears so resistant to stable interpretation. ${ }^{1}$ The proofs of Tormento are available for consultation in the Casa-Museo Galdós in Las Palmas de Gran Canaria and comprise 266 heavily-annotated pages. What is clear from them is that the proof stage of the publishing process was a crucial step towards the novel's composition rather than an exercise in putting the seal of approval on a definitive text. Galdós's typesetters must indeed have required the patience of Job when they saw the several thousand sometimes lengthy amendments he inserted. ${ }^{2}$ The purpose of the present article is, thus, simple: namely, to examine the modifications the 
author made to his proofs in order to understand better how he sought to finesse his characters and their complex circumstances in the novel's final version.

Before that discussion can take place, however, we must first outline the territory on which the battles over Tormento have been fought. Looming large here is the question of how to read the novel's female protagonist, Amparo Sánchez Calderón. ${ }^{3}$ At the outset she is a young working-class woman clinging to an evermore precarious position in society. She is living in a dingy apartment with her sister Refugio and the two of them are trying, and failing, to earn their keep as seamstresses. They are moreover orphans with no financial safety net to catch them, should they fall into destitution. Over the course of the novel we learn that Refugio, weary of their unremitting poverty, has decided to become an artist's model. That this is the first step on the slippery slope towards prostitution is confirmed in the novel's sequel, La de Bringas (1884). Amparo, too, bears a shameful and potentially ruinous secret: she has lost her virginity to a defrocked former priest, Pedro Polo, with whom she conducted an affair over an unspecified period. How long their liaison lasted we cannot know for certain. All that we glean from Tormento is that Amparo has deliberately avoided contact with Polo for the six months preceding the novel's action.

As well as bearing the cross of her shame, Amparo suffers for her inability to elude the tutelage of her relative, Rosalía Pipaón de la Barca. To outward appearances, the latter has taken Amparo under her wing following the death of the young woman's father but in truth has welcomed her only in the capacity of poor relation and unofficial servant. Amparo, thus, gets the worst of both worlds; not only must she endure Rosalía's limitless condescension, she also has to put in a full day's work of errands and cleaning for whatever beggarly sum Francisco Bringas can skim off the weekly budget. And yet, it is in the Bringas' home that Amparo glimpses the possibility of her salvation in the shape of Agustín Caballero, an "indiano" newly returned from thirty years trading in the United States and Central America that have made him one of the wealthiest men in Madrid. Caballero is attracted by what he regards as the young woman's beauty, modesty, and self-abnegation. Both are painfully shy and they reach a mildly imperfect understanding that they will marry, one that eventually firms up when Rosalía takes her former servant in hand to organize the purchase of her trousseau and linen for the marital home. Rosalía is, needless to say, appalled at Caballero's behaviour (she had been rather hoping that he would marry her own daughter so that she could ferret in his deep pockets, but Isabelita is still only ten). Just as Amparo's 
future prospects look secure, Polo contacts her, begging his former lover to come to his aid. He has fallen on hard times after renouncing his vocation. Deprived of the income from preaching, he has also been forced to close the school he ran after word leaked out of the appalling physical abuse he inflicted on the pupils. He by turns begs, cajoles, and threatens Amparo but is eventually convinced to leave her in peace by his former colleague, padre Nones, who sends him away to Toledo on a restorative break from urban life and its temptations. No sooner has this threat to Amparo's future been addressed than another emerges in the shape of Marcelina, Polo's sister. As ill-luck would have it, she has by chance found among her brother's papers certain love letters Amparo and Polo once exchanged and it is only a matter of time before her friend Rosalía also learns of their existence. Amparo, meanwhile, has been consulting her confessor and steeling herself to admit her past indiscretions to Caballero. Her fiancé has, however, developed a graven image of her as the embodiment of all virtue and she has neither the courage nor the will-power to shatter that illusion. In the meantime, a perfect storm is brewing. Rosalía and Polo learn almost simultaneously of, in the former's case, Amparo's dishonour, and in the latter's case, her betrothal. He wastes no time in returning to Madrid and summons her to his lodgings, keeping her prisoner there while trying to blackmail her into one final tryst to buy his silence. She eventually leaves with her dignity intact, thanks once again to Nones. The delighted Rosalía makes clear to Amparo that the secret is out. She rubs salt in the wound by referring to her former servant's having got above herself and puts her to work once more in the Bringas household. Assuming that all is lost, Amparo attempts suicide in Caballero's home by taking what she believes to be poison. Fortunately for her, the servant she sends out for the prescription is Felipe Centeno who substitutes an innocuous painkiller for the would-be lethal dose. In the meantime, the rumours circulating about his future bride finally reach Caballero's ears and he visits Marcelina to seek confirmation of the existence of the love letters. She unexpectedly refuses to tell tales, however, and throws the bundle of pages onto the fire before he can learn their content. Despite Rosalía's best efforts to stir his wounded pride and honour, Caballero decides to forgive his former fiancée and they set off together at the novel's conclusion for a new life in Bordeaux. To the lasting vexation of the novel's readers and critics, however, the couple will live unmarried and, therefore, by contemporary standards, beyond the pale of decency. Caballero judges Amparo's conduct to have made her unworthy to be his wife, but she can be his mistress for the foreseeable future. 
What we are to make of this denouement is not clear. Is this a triumph for conservative or liberal values? A blow for feminism or against it? Galdós lets his novel speak for itself and, with the exception of their brief appearance in the background of La de Bringas (limited to offering to host the Bringas family on holiday in France), did not return to Caballero or Amparo in the remainder of the "novelas contemporáneas" project. They therefore differ from Isidora Rufete, say, the protagonist of La desheredada (1881), whose absorption into the anonymous crowd of Madrid's street walkers would have been her fictional epitaph, were it not for her reappearance as the companion to an impoverished dying artist in Torquemada en la hoguera (1889). More importantly, they also differ from León Roch and Pepa Fúcar, the star-crossed lovers whose painful resignation to a life apart, in spite of their devotion to one another, formed the climax of La familia de León Roch (1878). Galdós evidently recanted of the pessimistic conclusion to that early novel since we learn in $L o$ prohibido (1885): “...vi a Cimarra [Pepa's lawful husband], que se había reconciliado con su suegro, el marqués de Fúcar, y resignádose a que su mujer viviera maritalmente en Pau con León Roch" (Galdós, Lo prohibido 277). Or, in other words, the retreat from Spain's prurient disapproval and movement towards the relaxed social attitudes across the Pyrenees becomes, for the second time, Galdós's preferred solution to the issue of how an unconventional couple may find a route to happiness. And yet, the silence around the fate of Amparo and Caballero is absolute and can be filled only with speculation which, though potentially infinite, is also utterly fruitless.

This is not to say that the loose trilogy of novels in which Tormento occupies the central position (the other two are El doctor Centeno and La de Bringas) does not offer substantial information as to how to interpret Amparo's fate. I have argued elsewhere that a range of factors coalesce to make clear that our sympathies should lie more on her side than on that of her principal antagonists, Pedro Polo and Rosalía de Bringas (Wood). Those factors include the role of Felipe Centeno from El doctor Centeno to its sequel, Polo's depiction in those same novels, and Rosalía's deserved comeuppance in La de Bringas. My views therefore coincide with those of Elizabeth Amann, Rodolfo Cardona, Sherman Eoff, Collin McKinney, José Montesinos, Geoffrey Ribbans, and Diane Urey, all of whom argue for a broadly sympathetic reading of Amparo's dilemma. Rather than summarize their arguments here, I propose to look in detail at the case for the prosecution, to examine whether or not it will stand up to scrutiny alongside Galdós's modifications to his proofs. 
Alicia Andreu, Peter Bly, Lou Charnon-Deutsch, Eamonn Rodgers, and Rodney Rodríguez are the most prominent critics who have sought to make Amparo the villain of the piece. Charnon-Deutsch takes the view that Galdós is urging his readers to extrapolate outwards from the home setting Amparo and her sister inhabit, the squalor of their flat offering a window onto the depravity of their inner lives. Hence "she is a hypocrite in her dealings with Refugio, her abandon of Polo is cruel and her secrecy with Caballero a betrayal. It must be accepted that morally Amparo is as ill as her decrepit apartment" (Charnon-Deutsch 40). Why this approach to setting should yield more conclusive results than consideration of the manifold passages where Amparo's thoughts and behaviour are scrutinized in detail by the narrator never becomes clear. ${ }^{4}$ Bly's criticism of her likewise focuses on her behaviour towards Polo: “Amparo's essential egotism, all the more discernible in her final, excited acceptance of Agustín's offer to become his mistress, leads her to a heartless rejection of Polo that is really criticized by Galdós" (Bly 394). Despite the presence of that "really," Bly says no more about precisely how Amparo's actions are criticized by the novelist. As we shall see later in this discussion, scrutiny of the proofs would indicate that Galdós was anything but critical of her decision to plan a future away from Polo and his influence. And yet, it is here also that Rodgers finds her actions most wanting, believing her rejection of Polo to be callous, selfish, and motivated by pure greed. He finds her "too wrapped up in her own concerns to see how necessary she is to Polo's well-being or to realize that if she were to join him in his quest for a more purposeful ... existence, there would be a greater prospect of this quest succeeding" (106). This rather leaves out of account the possibility that Amparo may have autonomous ambitions and a mind of her own. It is regrettable that Rodgers never indicates why, in his view, these should implicitly be side-lined so that Amparo can act as Polo's social crutch. While Rodgers would have it that "in repudiating [Polo] she may well be turning her back on something very genuine" (98), a robust response might ask why Polo's efforts to blackmail her into sleeping with him, his threats to rape and suffocate her, or his imprisonment of her for several hours do not eclipse his alleged merits as a potential spouse.

Rodgers's argument hinges on what I suggest is a crucial misstep in his consideration of the novel's dual structure. As has been well remarked, the novel "is constructed around the contrast between two alternative versions of the same reality" (96). Galdós sets up the juxtaposition in the opening chapter, a dialogue between José Ido del Sagrario and Felipe Centeno written out as if it were theatre script. Ido informs Felipe that he has made good on his intention, voiced at the conclusion of El doctor 
Centeno, to live by his pen. He has started writing "folletines," under the guidance of a more experienced hack-writer. Having discovered an apparently effortless facility for churning out pulp fiction, he has decided to embark on his own independent projects and his latest serial is to be based on real people: specifically, an idealized version of the lives of the two sisters who inhabit his same building - Amparo and Refugio. Thus, while Galdós's more obviously realistic depiction of their struggles follows from this, the reader obtains glimpses of the fanciful alternative, for example when Refugio visits Ido's flat to hear the latest twist in his romanticized retelling of their lives. Rodgers rightly avers that Galdós develops this structure to "suggest that sentimental fiction is one of the many conventional ways in which people falsify reality in accordance with their own preconceptions" (97) However, Rodgers immediately adopts a Marxist perspective in alleging that Galdós is intent on exposing bourgeois ideology and the "validating context within which relationships and motivations which are fundamentally economic may be rationalised as something else." For that reading of the novel to withstand scrutiny, it would have been necessary to demonstrate the continuity of such a radical ideology through the "novelas contemporáneas" or at least elsewhere in Galdós's published works. Put simply, why should the novelist have marched under a Marxist banner in Tormento when he showed himself to be nothing of the sort in any of his previous or subsequent writings? Having determined that this is the driving force behind Galdós's critique, Rodgers finds himself arguing that Amparo is calculating and callous when she may instead be as much the victim of an unequal society whose economic and moral stringency allows her precious little room for manoeuvre. What is undoubtedly the case is that Galdós's depiction of prerevolutionary Madrid exposes the many and varied bastardizations of reality perpetrated by its inhabitants for their own benefit. ${ }^{5}$ Indeed, Tormento takes considerable pains to denounce what passes for charity, civilization, marriage, morality, and religion in the Spain of 1867-1868, but Amparo is far from being its most egregious manifestation. We shall return to these points shortly in the discussion of the changes in the proofs.

The other critics whose views coincide with Bly et al. are Rodríguez and Andreu. Rodríguez would have it that the novel's dual structure has a yet further dimension: the deliberate deception perpetrated against the reader by the narrators of both the "idealized" and the "realistic" versions of Amparo's life:

Ultimately, the reader sees beyond the surface story that depicts the social and economic reality of a meek girl victimized by men who take advantage of her 
weakness and poverty; the reader penetrates to the deeper reality of a cunning, ambitious woman who ruthlessly deceives men, exploits them, and then casts them aside for a better match. The motif of deceit that runs through the narrative is reflected in the novel's narrators, who distort and destroy evidence in order to mislead the reader. (Rodríguez 76)

Ribbans has offered a superb riposte to this questionable conclusion and the tendentious interpretations on which it is based. With that in mind, I propose not to let it detain us any further here. ${ }^{6}$ Instead, what will emerge in the discussion that follows is that the text of Tormento, far from concealing details about Amparo's conduct, scrutinizes it robustly. That analysis will thus also refute Alicia Andreu's contention that the novel's protagonist remains ensnared by the romanticized vision of life peddled by sentimental fiction:

Este sentimentalismo [de las heroínas románticas] que la define y que define también el concepto que la humilde muchacha tiene de la vida - tiempo y espacio impide que Amparo adquiera un autoconocimiento que la impulse a romper con la dualidad temporal en que se mueve. Alienada de la más remota posibilidad de que esto ocurra, nos encontramos con una protagonista que existe en el hoy, desesperada por borrar el ayer e ignorante de la existencia de aquel futuro que implica liberación. Al final de la novela, como amante de Agustín, y alejada de Madrid, la protagonista del texto realista continúa siendo lo que era bajo la tutela de los Bringas, un signo lingüístico lejano, distante, semejante al de las heroínas virtuosas del folletín. (Andreu 58)

Rather than lacking fictional and personal plenitude by the conclusion of the text, this article will argue that she more than achieves both.

What has emerged from this consideration of the arguments against a sympathetic reading of Amparo's predicament indicates that we might usefully categorize them as follows. First, there is the suggestion that Amparo is a calculating woman, driven by greed and self-interest. Secondly, there exists a view of Polo as a wronged lover carelessly cast aside who might have offered Amparo a rosy future had he been given the chance. Thirdly, there is the suggestion that the two alternative versions of the sisters' fortunes deliberately conceal the reality of Amparo's conduct from the reader. And fourthly, we must address the idea that she remains mired in an infantilized and sentimental worldview. In the remainder of this article, I propose to examine each of these arguments and determine whether or not Galdós's changes in the proofs can shed significant light on 
them. The first two points will be addressed sequentially; points three and four will be examined together.

To test the first of these suggestions - that Amparo is a coquette who calculatingly sets out to ensnare Caballero - it is worth remarking the changes Galdós made to two telling passages of his proofs and which affect how she is, quite literally, observed by the reader. In chapter ten, the narrator draws an explicit distinction between Amparo and Refugio, one that associates the latter with a wanton sexuality and the former with a more discreet beauty. Thus Refugio: "Pero lo más llamativo en esta joven era un seno harto abultado, sin guardar proporciones de imponente interés para la escultura, semejantes á las que dieron nombre a la Venus Calipija." Galdós added to this already objectifying description by inserting, after "proporciones," "con su talle y estatura. La ligereza de su traje en aquella ocasión acusaba otras desproporciones" and allowing the remainder of the sentence to run on. By contrast, Amparo is possessed of "hermosura grave, a la vez clásica y romántica, llena de melancolía y de dulzura, habría podido inspirar las odas más remontadas, idilios tiernísimos, dramas patéticos, mientras que la otra era un agraciado tema de anacreónticas o de invenciones picarescas." The second amended passage appears to puncture the suggestion that Amparo is a seasoned woman of the world, well used to the searching male gaze. It occurs in chapter thirteen during her furtive journey to Polo's lodgings and originally read:

Las diez serían cuando se echó a la calle, digámoslo en términos revolucionarios, y tan medrosa iba, que se consideraba observada y aun seguida por todos los transeúntes. ¿La observaban afectuosamente ó era que ella, en su azoramiento, lo creía? Era un sobresalto, un pánico, que salía sin duda de su propia conciencia, porque la verdad era que nadie se cuidaba de ella como no fuera para admirarla por bonita.

Galdós excised all but the first sentence of this passage. He seemingly wanted to remove the implication that Amparo, once dishonoured, is "public property" to be admired at will by all and sundry.

To examine further the claim that she is a cunning seductress, there could scarcely be a better place to do so than chapters eight and nine, the "courtship" scene. It is there that Caballero first makes his shy and inhibited intimations to Amparo that he has developed feelings for her. On the face of it, the suggestion of calculation on her part would appear nonsensical for the obvious reason that she has not engineered the scene, rather Caballero has, by sending the Bringas household off to the theatre 
for the night. Those best-laid plans had looked in jeopardy due to an illness afflicting one of the children but Amparo is left to see to any emergency and Caballero is able to secure the private interview he has been so anxious to obtain. What becomes clear, however, is that even within this framework, Galdós took care to nuance Amparo's presentation and to remove the hints of calculation that had persisted from an earlier draft. Thus, he altered the following paragraph:

La fisonomía del salvaje era poco accesible generalmente a las pesquisas del observador; pero el observador en aquel caso y momento pudo haberse arriesgado a dar a la expresión de aquel rostro la versión siguiente: "Ya sabía yo que esos majaderos estaban en el teatro y que la encontraría a usted solita".

Galdós removed the word "pesquisas" and replaced it with "interpretaciones." We might speculate that his reason for doing so depends on the fact that, although the narrator is making a general remark about Caballero, the only implicit observer "en aquel caso y momento" is Amparo. Were she to be subjecting him to "pesquisas" rather than simple "interpretaciones" it could be argued that she was fishing for information: "pesquisas" are, after all, more active and studied than arriving at "interpretaciones." An analogous desire to remove the air of calculation appears to determine the removal of Amparo's over-done theatricals during Caballero's account of the hardships he endured in Central America:

- Jesús, iqué horror!...

Amparo se cubrió la cara con sus manos.

- ¿ ¿Y piensa usted volver allá? - dijo, sin dar tiempo á que Caballero diera verdaderas explicaciones sobre la verdadera fauna de aquellos países.

Here Galdós removed the sentence beginning "Amparo se cubrió" and instructed the typesetter to run the two speeches together, which is how the final version reads. Caballero's "courtship" of Amparo hinges, just as Othello's does of Desdemona, on his accounts of hardship overcome in farflung lands; except, of course, that Caballero lacks nearly all of Othello's oratorical flare. Nevertheless, this amendment removes Amparo's histrionic playing up to the role of the weak female awed by the allconquering male.

At the proof stage, the conclusion of chapter eight had originally included a substantial ironic commentary on Caballero's inhibition, the shyness that has seen him try and fail to make a clean breast of his feelings 
for Amparo: "Los mudos suelen ser elocuentísimos cuando se dicen las cosas a sí mismos. Pero el terreno estaba tan bien preparado, la ocasión era tan propicia, que por fin el cohibido y temeroso indiano se sentía con aliento para arrojar de sí todo, todo lo que había pensado." But Galdós decided to remove the entire second sentence, erasing any possible interpretation that he has been "set up" for this scenario by Amparo's cunning.

The "courtship" scene presents a tussle between two people who, for different reasons, experience debilitating constraint. Caballero is tonguetied because he remains unused to expressing his more intimate emotions. Amparo knows she must help to draw him out but wants to avoid appearing too eager. The narrator even comments that she comes close to overstepping the mark: “... indicó Amparo quizás con demasiada familiaridad." But she is not a complete ingénue and knows that Caballero has not appeared there entirely by chance. This idea was originally reinforced in the proofs by the following passage: "Amparo, por admirable instinto y penetración natural comprendió que Agustín tenía dentro algo más que aquel vaya, vaya tan fino, tan incoloro, tan insulso, y se atrevió a explicar de esta manera". However, he thought better of the word "instinto," arguably because of its range of semantic associations around predation and securing a victim, and amended the text to read "Amparo, con su penetración natural." Other changes included "fino" becoming "frío" and "explicar de esta manera" replaced with "estimularle así".

It is not for nothing that Amparo must tread carefully since, implicit within the tussle for mutual understanding between her and Caballero, is a defining decision over her future. Will she enter a convent or marry a millionaire? As Ribbans has suggested, the fact that women were faced at this juncture with a choice of the convent, marriage or prostitution "is surely not a situation which should be accepted, by contemporaries or later readers, with any satisfaction; and it makes natural and morally justifiable whatever strategy of survival such a woman may adopt" (505). In the proofs, Amparo voices her frustration during that same conversation with these words: "En qué condición tan triste estamos las pobres mujeres que no tenemos padres, ni ocupación lucrativa, ni familia que nos ampare." Galdós changed her wording from "ocupación lucrativa" to "medios de ganar la vida" to emphasize that not only is she unable to make enough money to live comfortably, she cannot make enough money to live at all. And while her giving vent to this lament is undoubtedly strategic, there is nothing in the text to suggest that it is anything other than objectively true. ${ }^{7}$ 
Further changes give possible endorsement to that same sentiment; for example, when Galdós puts an eloquent protest against the situation in the mouth of Caballero. The author moreover took pains at the proof stage to draw attention to the rhetorical flight the sheer injustice of Amparo's situation inspires in Caballero:

Agustín sintió que el rubor ¡cosa extraña!, subía a su rostro caldeado y seco. Era como un árbol muerto que milagrosamente se llena de poderosa savia, el corazón le latía con fuerza, y tras aquellas palabras vinieron estas.

‘Meterse monja! Yo creí que ya no había conventos! ¡Qué atraso! Eso es de países muertos. ¡Mendigos, curas, empleados; la pobreza autorizada y reglamentada!...'

In order to better emphasize the heights to which his righteous anger helps this usually taciturn man to soar, Galdós inserted after "savia" an extension to the simile: "que milagrosamente se llena de poderosa savia y echa luego en su más alta rama una flor momentánea. El corazón le latía con fuerza..." In the rest of the passage, Galdós changed Caballero's designation of Spain's "pobreza autorizada y reglamentada" into "pobreza instituida y reglamentada," perhaps to emphasize the extent to which unjust social structures are centrally engineered at the institutional level of the State. This passage serves as an early example in the novel of Caballero's growing sense of Spain's endemic putrefaction, a sense that will eventually see him quit the country altogether.

The cumulative effect of these changes appears therefore to indicate an author taking care to excise suggestions of calculation on Amparo's part. She treads - and knows she is treading - a fine line. On one side lies a prosperous and respectable future, on the other uncertainty and drudgery. As the text of the "courtship" scene makes clear, Amparo has serendipitously composed a tableau whose detailing could scarcely have been more artfully composed to appeal to the conservative, home-making instincts Caballero has formed after so many years in the wilds of MexicanAmerican border:

Cansada del trabajo de aquel día, sentose Amparo junto a la mesa del comedor, donde había quedado la lámpara encendida, y se entretuvo en hojear un voluminoso libro. Era la Biblia, edición de Gaspar y Roig, con láminas ... A las láminas más que al texto atendía la fatigada joven; pasaba hojas y más hojas con perezoso movimiento, y así trascurrió algún tiempo hasta que la campanilla de la puerta anunció una visita... (198) 
Catherine Jagoe and Alicia Andreu have developed independent but complementary analyses of Galdós's interest in the motif of the "ángel del hogar:" the idealized female homemaker so favoured in the middle period of the nineteenth century by Catholic ideology, female conduct manuals, and sentimental fiction. What is clear is that rather more by good luck than good judgement, Amparo has come to supply the female form onto which Caballero can project all of his dearest fantasies of pure, self-abnegating femininity. By the end of the novel, he will be obliged to revise his views not only of Amparo but also of the viability of those same ideals. In the meantime, before leaving the courtship scene behind in our discussion, it is worth remarking that another telling change Galdós made to his proofs was to present a future with Caballero as a more realistic proposition than his earlier initial draft had allowed for. The passage in question occurs in Caballero's would-be declaration of love to Amparo, the declaration his inhibitions will not allow him to deliver but which he rehearses in his head for most of chapter nine. He describes his desire to return home and establish a model of traditional domesticity: "Por la travesía pensaba así: 'Gracias a Dios que vuelvo vivo, aunque muy rendido y quebrantado. Pero ahora, en la vieja Europa, pobre y ordenada, encontraré lo que me falta, sabré completarme y redondear mi existencia."' Galdós opted to remove his protagonist's pessimism over his physical health, the final version reading instead "pensaba así: 'Ahora, en la vieja España, pobre y ordenada..."' He evidently wanted his readers to be left with the impression that Caballero and his bride could be physically compatible. And so it is that our only significant physical description of him remains the narrator's gentle admiration, rather than Caballero's own downbeat self-assessment: "Siempre vi en Caballero una vigorosa constitución física, medio vencida en ásperas luchas con la Naturaleza y los hombres; una fuerte salud gastada en mil pruebas; una hermosura tostada al sol" (Galdós, Tormento 173).

That change could scarcely be more significant, given the substantial shift in emphasis Galdós would undertake later in those same proofs concerning Pedro Polo. As we saw above, Charnon-Deutsch, Rodgers, and Rodríguez all allege that Amparo's rejection of Polo is a heartless turning away from a man who either needs or deserves her affection. Ribbans (497-503), Caudet (Galdós, Tormento. Ed. Caudet 45), and I (Wood 393) have argued by contrast that Polo's seduction of Amparo reads in fact as a sordid piece of opportunism on his part: his age, position as a man of the cloth, family relationship to her (he is her mother's cousin), and awareness of her vulnerability as an orphan ought to have dissuaded him from permanently dishonouring her. But, as in every other area of his life, he 
instead succumbed ignobly to his baser instincts. There is no doubt that Galdós is aware of the pathos in Polo's situation but that does not alter the fact that the former priest has done Amparo a great and lasting injustice. Those critics who look more benevolently on him, and even see a future for him and Amparo, ought to bear in mind passages where Polo's intrinsic inadaptability to life in modern society is described by the narrator. Above all, they should note the lengthy passage Galdós inserted into the conversation between Marcelina and Caballero when the latter has gone to the former's home to verify the existence of the incriminating love letters. Hitherto, Marcelina had given every indication of belonging to the unbending "beata" archetype that would have been more at home in Galdós's "novelas de la primera época." She had placed the blame for her brother's disgrace squarely at Amparo's door and has informed Rosalía accordingly. It is thus with some surprise that we learn of the beneficent effects - not for the first time in the novel - of padre Nones, who has managed to convince her that the letters belong either in the hands of their authors or on the fire: "...seguiré el consejo del padre Nones, que me ha dicho: 'O entregarlo a su dueño o a las llamas"' (Galdós, Tormento 422). Not only this, but she has also revised her view over where to apportion the blame for the affair. At the proof stage, the relevant passage originally read: "Pues allí, en aquella isla de Zamboanga, mi hermano convertirá herejes y hará grandes méritos. Y mienten los que le suponen mal natural; pues si no le hubieran sorbido los sesos otro gallo le cantara." Rather than leave matters there, however, Galdós inserted the following substantial passage:

No es esto decir que confíe absolutamente en la salvación, pues como la cabra tira al monte, el vicio tira siempre ... á lo que tira. ¡Oh! ¡qué esfuerzos tuvimos que hacer á última hora. Si hubiera V. visto...! ¡Qué hombrazo! En la estación nos decía que allá será un Nabucodonosor con sotana. Que sea lo que quiera con tal que no vuelva á las andadas, ni parezca más por acá ... Y no crea V... ¡tengo un susto...! Se me figura que de Barcelona ó de Marsella se nos vuelve á Madrid y se me entra por la puerta cuando menos lo espere ... V. no le conoce bien.

In other words, Marcelina now believes that "como la cabra tira al monte, el vicio tira siempre ... á lo que tira". Even when she envisions her brother's future on another continent and with Amparo far behind, she cannot be sure that the vices she now, by implication, believes are intrinsic to his character will not play him false yet again. The fact that Galdós wished to emphasize how eager Polo's own family are to see the back of him makes 
untenable any suggestion that Amparo has a "duty" to shoulder the burden of his erratic behaviour and poisonous personality alone.

The narrator had explored in chapter fourteen just how wayward Polo's life had become in the time that has elapsed since he last appeared in El doctor Centeno. In what are the most overtly Naturalistic passages in Tormento, Polo's inability to overcome his inherent tendencies is laid bare: "Se desquició de golpe todo aquel mal trabado edificio ... siendo muy de notar que no se debió esta catástrofe a lo que tontamente llama el vulgo mala suerte, sino a las asperezas del carácter del caído, a su soberbia, a sus debocadas pasiones, absolutamente incompatibles con su estado" (Galdós, Tormento 250); "Él había nacido para domar salvajes, para mandar aventureros, quizás, quizás para conquistar un imperio como su paisano Cortés" (Galdós, Tormento 252); "Su mente, ávida de la sencillez y rusticidad primitivas, había perdido el molde de aquellos hinchados y vacíos discursos ... Era un hombre que no podía prolongar más tiempo la falsificación de su ser, y que corría derecho a reconstituirse en su natural forma y sentido" (Galdós, Tormento 254). As each of these passages makes clear, Polo's natural habitat would be an environment stripped of the niceties of respectability and artifice. He is quite simply not strong enough to keep his passions in check. Collin McKinney has rightly suggested:

Whereas Agustín displays a figurative savagery in his lack of social refinement and childlike naïveté, Polo's savagery is literal and visibly physical as he acts on carnal instinct alone. In this respect he resembles the degenerate criminal, described by Lombroso and other criminal anthropologists at the end of the nineteenth century, more than the noble savage. (McKinney 106)

When we take this insight alongside the numerous occasions Caballero is referred to with variations on "bruto," "salvaje" and their cognates, we can see that a thought-provoking antithesis is being established between Amparo's two suitors. While Caballero's move has been a return from the American bad-lands to civilization, Polo's move will take him from the heights of imposed respectability to the untamed and unknown wilds of the Philippines. But, as the text makes abundantly clear, so-called civilization is merely the mask worn by a society riddled with vice. Galdós took care to reinforce that very point when amending his proofs. One example is a passage from Caballero's interior monologue as he chastises himself for leaving his familiar life on the frontier and trying to adapt to a hostile environment: "¿Quién te manda a ti salir de tu terreno, que es la salvaje comarca fronteriza, donde los hombres viven como las bestias?." The author removed the word "salvaje" and replaced "como las bestias" 
with "pegados al remo de un trabajo duro" (while the final printed version replaced "duro" with "tosco"). Although the life he left behind lacked the trappings of comfort, Galdós wishes at this late stage to highlight its values of hard work, rather than its untamed rusticity. These modifications also signal and prepare the reader for Caballero's realization that the civilized values to which he had dreamt of a return are not to be found in the Spain of 1868 .

In the following chapter, Caballero continues the self-reproaches, but Galdós importantly changes the terms in which they are couched: "Te has lucido, pedazo de bárbaro" becomes instead "Te has lucido, hombre insociable," leaving greater room for doubt as to whether he is merely unable to adapt to this society; "este yo falsificado y postizo que quería amoldarse á las formas de la civilización" becomes the more temporally remote and equivocal "que quiso amoldarse á la viciosa cultura de por acá" (the change from imperfect to preterite tense of the verb expresses how remote that once cherished desire has become; the change to "viciosa cultura" speaks for itself). And finally, "yo digo a la sociedad toda que me la pongo por montera, y á la ley, si ley es, que la escupo ... y nada más, y hágase mi santísima voluntad" becomes "yo digo a la Sociedad que toda ella y sus arrumacos me importan tres mil [this changed to 'cuatro' in the final version] pitos, y me plantaré en medio de la calle, si es preciso, gritando: ¡Viva la inmoralidad, viva la anarquía, vivan los disparates! [this final clause was absent from the printed version]." This last change imbues his stance with greater reasoning: he wants to take a public stand against this society and not just thumb his nose at it in private.

Caballero decides to forgive his former fiancée for a number of reasons. On the one hand, he has come to see that the individuals and the social norms that would condemn her lack the moral authority to do so. He is also sexually attracted to her, attested by the imagery he employs to express his regret at losing her: "La manzana que cogí pareciome buena. Ábrese y la veo dañada. ¡Me da más rabia cuando pienso que la parte que aún conserva sana ha de ser para otro" (Galdós, Tormento 434). The decisive step towards their reconciliation is, however, the private interview they share in chapter thirty-nine. The proofs of that scene show Galdós finessing his prose to heighten the harmonious tone. He is also anxious to emphasize that Amparo has grown in stature. Her suffering has given her the resolve to clear the air that she could not previously muster, with the effect heightened by her sense of Caballero's almost intimidating physical strength as they clasp hands prior to his would-be departure: she speaks up despite knowing that she has angered such a powerful and influential man: 
La que agarraba la suya tenía fuerzas sobrenaturales. Y en verdad, ¿cómo dejarle partir sin una explicación? Aquel sí que era oportuno momento. Pasada la primera vergüenza, la confesión se salía de la boca, libre, fluida sin tropiezo, con pedazos del alma, toda verdad y sentimiento.

Cuenta Nicanora que al abrir la puerta de la sala les vio sentaditos el uno junto al otro, las caras bastante aproximadas, ella hablando en voz baja, él escuchando con toda su alma, como los curas en el confesonario.

The additions to this passage included a change of the opening words to "La mano ajena," perhaps to heighten the movement from estrangement to reconciliation. The harmony of their exchange is emphasized by the replacing "ella hablando en voz baja, él escuchando con toda su alma" with the pleasing balance of "ella susurrando, él oyendo con sus cinco sentidos" (although the published version reads "atendiendo", probably to remove the destabilizing implications of synaesthesia implied by hearing with "cinco sentidos").

It can hardly be accidental that Galdós uses the vocabulary of the confessional to provide the symmetry of poetic justice in Amparo's life (later in the proofs of the same paragraph he changed her designation from "Amparo" to "la penitente"): dishonoured by a priest, it is only in making true confession to a secular stand-in that she can move forward with her life. At its conclusion "tenía la cara radiante, los ojos despidiendo luz, las mejillas encendidas, y en su mirar y en todo su ser un no sé qué de triunfal e inspirado que la embellecía extraordinariamente" (Galdós, Tormento 439). As yet, she has no idea of what will come of her confession, but what the passage makes abundantly clear is that unburdening herself telling the truth - matters to her irrespective of whether or not she will thereby earn a place at Caballero's side. ${ }^{8}$ The denouement of the novel therefore calls into quesion Andreu's analysis of Amparo as still mired in sentimental fictions of her own past. She grows in stature and, more importantly, regains control over the two things Polo, Rosalía, Marcelina, and Ido had seized - her dignity and her narrative. McKinney has suggested that the elopement with which the novel ends "allows Agustín to keep his masculinity intact by avoiding marriage. Amparo, meanwhile, is pushed further away from the ángel del hogar ideal. And while departing from the ideal will inevitably lead to social ostracism, it frees her from a constrictive ideal and grants her a degree of agency" (McKinney 100).

We might take his conclusion one step further and argue that Caballero now knows her to be in possession of a sexual identity. Once she no longer occupies the pedestal of the "ángel del hogar" archetype, he is 
able to see her as a real woman rather than the asexual embodiment of virtue he had previously imagined. As Jagoe has observed, the "'ángel del hogar' archetype is itself riven with contradictory valences, envisioning a being who is 'supposedly powerful yet materially powerless; imaginatively invested with wings yet imprisoned; supposedly busy yet enforcedly idle; supposedly sexless yet at the same time devoted wife and mother; always content even though a prisoner'" (41). Could it be that Caballero and Amparo have stumbled imperfectly upon an ideal footing on which to start their union? Caballero may well appreciate cohabiting with a woman he knows to possess a number of good qualities but whom he also knows to have sexual needs. And Amparo may well be happier to live alongside a man who knows that too. With all this in mind, it seems a genuine pity that Jagoe's study of how Galdós engages with the "ángel del hogar" archetype does not make Tormento part of its analysis. Whereas Jagoe situates a mould-breaking problematization of its stable binaries in the figure of Fortunata, our analysis of this earlier novel has thrown up issues that would situate the shift in perspective somewhat earlier in Galdós's career (Jagoe 109). McKinney strikes a happy balance in his assessment of the extent to which the novel subverts those archetypes:

It would be too strong to argue that Galdós's texts succeed in deconstructing the existing gender paradigms, but there is certainly a whiff of subversion in his representation of what constitutes acceptable masculinity and femininity. The very absence of conventional ideal men and women from the pages of these novels exposes the unattainable nature of Spain's existing gender ideology. In Tormento the narrator's sympathies do not depend on adherence to the established ideals. Because the actions taken by Amparo and Agustín at the end of the narrative transgress the limits of conduct supported by the bourgeois gender discourse, and because their actions are viewed with sympathy by the narrator, the text undermines the authority of that discourse (107).

From Caballero's perspective, Amparo's confession is the true actualization of his former, self-defeatingly hubristic claim to complete knowledge of her character: "Figurábame que poseía yo todos sus secretos y que ninguna particularidad de su vida me era desconocida" (Galdós, Tormento 207). He had returned to the old country expecting to found the model, god-fearing household as a palliative against years of spiritual disorder on his travels: "La soledad fue mi compañera, y en la soledad se nutrían mis tristezas a medida que crecía el montón de mis caudales. Amigos pocos, familia ninguna" (Galdós, Tormento 205). As his nostalgia-fuelled ideal hits the brick wall of reality, with its imperfect human beings and moral 
compromises, Galdós deliberately picks up the thread of religious imagery which had underpinned his character's now-shattered worldview. We have already seen that Amparo is transfigured into the apple of the Fall at the same moment Caballero is acknowledging (whether consciously or not) that he desires her sexually. We have likewise seen that Amparo's setting of the record straight is framed as a secular confession. That tendency continues in the proofs with the amendments to Caballero's immensely powerful interior monologue (chapter thirty-nine) in which he finally acknowledges to himself that the conservative paragon of domesticity he has pursued was founded on a series of self-deceptions. Its final words had originally read "No te fíes de la magnitud convencional de los principios y respete la majestad de los hechos" but Galdós amended them to read "No te fíes de la magnitud [although this becomes 'majestad' in the published version] convencional de los principios y arrodíllate delante del resplandeciente altar de los hechos ... Si esto es desatino, ique lo sea!." The shining altar of the facts, or of what has happened, is a long way from the rigid moral exigencies of an identity Caballero was trying to put on - he has now come to see - only for appearance's sake. Polo had earlier admitted in a rare moment of self-knowledge: "Sueño con romper por todo y marcharme allá, olvidando lo que he sido y matando de raíz el gran error de mi vida, que es haberme metido donde no me llamaban y haber engañado a la sociedad y a Dios, poniéndome una máscara para hacer el bu a la gente" (Galdós, Tormento 263). What is crucial about the contrast is that Caballero has realized with time enough to spare to avoid inflicting on others the damage Polo has wrought. Instead, Caballero's first action is to administer absolution, in yet another moment where Galdós sought deliberately to hammer the point home to his readers:

Concluido el soliloquio con otro gran suspiro, Agustín se acercó a la joven, y sobre la cabeza de ella puso su mano, en actitud parecida a la de los sacerdotes de teatro cuando figuran atraer sobre algún virtuoso personaje las bendiciones del cielo. Y no paró aquí la cosa, sino que le dijo:...

The insertions here included "mártir, neófito o cosa semejante," after "personaje" to alert those who had not yet got the point of what Caballero's actions are being equated to. The final "le" he replaced with "a la que fué su novia," seemingly to increase the dramatic tension on the cusp of his decision to forgive her and build their future together.

By adopting the gestures and rhetoric of sin, confession, and absolution, Galdós allows us to see that Caballero's self-deception had been substantial and potentially harmful to others, not least Amparo. But his 
critique does not extend to those values themselves. Rather, the focus is on what to do about human situations in which individuals (perhaps inevitably) fall short of the ideal. It becomes a question of what friends, acquaintances, and society at large do about those failures. Urey and Caudet have both seen an ironic anticipation of, and parallel for, this struggle between spirit and flesh, benevolence and judgement, in the passage from chapter three where we find Amparo and Rosalía de Bringas cleaning the latter's newly acquired home:

Así el polvo vuelve a la tierra después de haber usurpado en los aires el imperio de la luz; pero jay! la tierra lo envía de nuevo, desafiando las energías poderosas que lo persiguen, y esta alternativa de infección y purificación es emblema del combate humano contra el mal y de los avances invasores de la materia sobre el hombre, eterna y elemental batalla en que el espíritu sucumbe sin morir o triunfa sin rematar su enemigo. (Galdós, Tormento 154)

Caudet sums this up neatly with "las manchas como el polvo no se quitan nunca del todo. Pero tampoco ha de importar demasiado. Porque así es la realidad: una lucha imposible por la purificación absoluta" (54). For Urey too, this passage becomes an anticipation of the moral compromise and inexorable blending of identities with which the novel concludes: "Like the eternal cycle of water and dust, the one becomes the other in a process which forever turns back on itself. Amparo/Tormento is neither one nor the other, neither virtuous nor sinful, but a third thing, the mutual compromise" (55).

Until the novel's final passages, Amparo has lacked control over her destiny. Disempowered by her social position, she is also let down by her weak will and tendency to prevaricate. Galdós ensured that his amendments to the proofs of chapter sixteen, the culmination of her first re-encounter with Polo, highlighted the change in how both the narrator and the former priest name her. On a number of occasions, "Amparo" is amended to read "Tormento," a designation the young woman refuses at the end of that same chapter, as Diane Urey has observed: "as Amparo leaves, she un-names herself: 'Ya no me llamo Tormento', just as at her entrance into his rooms, Polo utters that name. Amparo seeks to assume a new identity by refusing a name; she attempts to be different from herself" (55). What Urey's formulation captures is indeed an essence of Amparo's dilemma: her dishonour will remain part of her identity however much she may wish to obliterate its memory and legacy. Those critics who would have it that the main narrator of Tormento deliberately conceals her affair 
with Polo need to explain what they think a passage such as the following, from that same chapter, is referring to:

En el corazón tenía la desventurada joven tantas dosis de arrepentimiento como en la conciencia, y no podía explicarse bien el error de sus sentidos ni el desvarío que la arrastró a una falta con persona que al poco tiempo le fue tan aborrecible ... Mas no osaba expresarlo así por miedo a las consecuencias de su franqueza, siendo de notar que si la caridad tuvo alguna parte en su visita, grande la tuvo también aquel mismo miedo, el recelo de que su desvío exacerbara al hombre y le impulsase por caminos de publicidad y escándalo. (Galdós, Tormento 265-66)

The narrator could not be much more explicit about what has transpired and still remain within the standards of propriety demanded by Spain's contemporary publishing industry. In fact, what the action in Tormento subtly mirrors are the ways in which Amparo's dishonourable secret would impinge on her existence in the real world. Hence why it is that, instead of the narrator supplying the reader with a banal account of how, where, and when, we learn of the affair in fragmented encounters as it rises out of Amparo's past to blight her present and future. It comes to light in precisely the ways one would expect in a gossipy and judgemental society. It emerges when it is the subject of rumour behind her back (Ido and Centeno in chapter one, the Rosalía-Torres-Mompous-Caballero chain of Chinese whispers in chapter thirty-five). It is thrown in her face by her sister Refugio when the two of them argue about money and morality (chapter twelve). It is used by others to blackmail her into accepting their control (Polo asking Amparo to buy his silence with sex, Ido trying to sponge employment for himself and his extended family, Rosalía stealing linen and finery when she learns of the guilty secret). It proves a persistent thorn in her conscience, not least at the crucial moment when Caballero first begins his clumsy courtship, as Urey has so ably shown (52-53). ${ }^{9}$ Thus, there is no deliberate concealment of what Amparo has done. Instead, the narrator's means of delivering the revelations precisely mirror the filtration and persistence of rumour, innuendo, and threat that Amparo must confront if she is to make any headway in the world. The "tormento" of the title is thus an allusion not just to Polo's pejorative nickname but also to her efforts to live down a shame that threatens to crush her.

In conclusion it is tempting to return to one of the very first readers of Tormento, Leopoldo Alas. He saw straight away that among the novel's greatest strengths was its attempt to depict women as real human beings, away from the artistically sterile binaries to which female characters were too often subject in contemporary fiction: 
...en general, la mujer está poco estudiada en nuestra literatura contemporánea; se la trata en abstracto, se la pinta ángel o culebra, pero se la separa de su ambiente, de su olor, de sus trapos, de sus ensueños, de sus veleidades, de sus caídas, de sus errores, de sus caprichos; les sucede a esas mujeres lo que a los personajes de nuestro teatro: llevan un nombre, pero no pueden llevar dignamente un apellido. (Alas 519)

As this discussion of Galdós's proof changes has shown, he is far from inviting his readers to view his heroine in the intellectually deadening black and white of moral opprobrium. If Alas could see this so clearly in 1884, how can critics of Tormento still be arguing about it 130 years later?

University College London

NOTES

$1 \quad$ Although the novel's most recent editors, Teresa Barjau and Joaqium

Parellada, consulted the proofs when preparing their edition of Tormento, they opted not to reproduce those modifications in their textual apparatus. Instead, they limit themselves to the following conclusions: "Por lo que se refiere a las [variantes que modifican el contenido del texto], hay que señalar que, si bien se observan añadidos de importancia, son más las supresiones: continúa así el trabajo de depuración textual que ya se había iniciado en Beta. Estas supresiones suelen tener como fin sugerir antes que afirmar, insinuar o dejar en el aire mejor que dar plena constancia de los hechos. Galdós seguía así un principio de elipsis o de elusión en el que llegó a ser un consumado maestro" (Galdós, Tormento 32). Michael A. Schnepf and Teresa Barjau and Joaquim Parellada have shown the considerable changes between the novel's earliest incarnation and the final edition. However, a full consideration of those changes, alongside the proof modifications, would require more space than that available here.

2 As will become clear in the following discussion, the changes made at the proof stage were, on a small number of occasions, not definitive. This occurs most often with single words - usually adjectives or nouns - which were subject to a final revision before the published version appeared. However, the proofs held in the Casa-Museo unquestionably represent a set of revisions that went a great distance towards producing the final version of the novel.

3 Until Geoffrey Ribbans pointed out the apparently ubiquitous error (497), critics of Tormento had consistently and without exception got the name of its 
central character wrong, calling her Amparo Sánchez Emperador. I therefore follow Ribbans is giving Amparo her correct designation.

4 Examples of passages in which Amparo's behaviour is subject to prolonged scrutiny would include (Galdós, Tormento 265-66; 298; 316-23; 328-29; 335; 346-50; 367).

5 The author evidently intended his critique of that era to resonate with his contemporary readers since his narrator comments in chapter four: "En una sociedad como aquella, o como esta, pues la variación en dieciséis años no ha sido muy grande; en esta sociedad, digo, no vigorizada por el trabajo, y en la cual tienen más valor que en otra parte los parentescos, las recomendaciones, los compadrazgos y amistades, la iniciativa individual es sustituida por la fe en las relaciones" (Galdós, Tormento 164).

6 Francisco Caudet is likewise in full agreement with Ribbans's refutation of Bly, Charnon-Deutsch, Rodgers, and Rodríguez, as he states in the introduction to his edition of Tormento: "Ribbans...está en desacuerdo con estos críticos. Comparto todos y cada uno de los argumentos de su desacuerdo" (45).

7 Geraldine Scanlon's researches on the earning capacity of seamstresses in the period Tormento is set also corroborate the suggestion that the remuneration for their work would never have kept pace with their needs, unless it was supplemented from elsewhere (83-85). Refugio also reinforces the point with her speeches at Galdós, Tormento 236, 342.

8 Eoff says of this scene: "The final dynamic scene for Amparo, however, comes with her confession to Caballero after he has decided to leave her, and represents her happiest and most scintillating moment: the swimmer has at last been able to plunge into the cold water. She is proud of herself, not because she has satisfied a sense of honor - her confession is nothing more than an admission of something that everyone already knows - but because she has conquered her timidity" (57).

9 Urey's analysis focuses on the moment Caballero finds Amparo alone in the Bringas home on the night he has dispatched the family to the theatre. He chances upon the young woman as she is looking at the plates in an illustrated edition of the Bible. Urey's analysis shows how the choice of Biblical verses alluded to in each of the three images is anything but fortuitous. Rather each in its own way reflects on the situations depicted in the novel, culminating with the third and final one, which alludes to the opening lines of Psalm 69, and the danger Amparo will sink forever into the mire of ignominy, prompting her to close the good book. 
WORKS CITED

ALAS, LEOP OLD O. Obras completas. 12 vols. Ed. Jean-François Botrel et al. Oviedo:

Nobel, 2002-2009.

alas, leopoldo and laureano bonet. “Crítica (Primera Parte)”. Obras

completas. Vol. 4. Oviedo: Nobel, 2003.

amann, elizabeth. "From Magasin to Magazine: Au Bonheur des Dames and

Galdós’s Tormento." Revista Canadiense de Estudios Hispánicos 28.3 (2003):

455-77.

ANDREU, ALICIA. "El folletín como intertexto en Tormento." Anales galdosianos 17 (1982): 55-61.

barjau, teresa and parellada, joaquim. "La génesis de Tormento a partir de los manuscritos." Isidora: Revista de estudios galdosianos 9 (2009): 49-64.

B LY, PETER. "From Order to Disorder: The Pattern of Arreglar References in Galdós's Tormento and La de Bringas." Neophilologus 62.3 (1978): 392-405. CARD ONA, R O D L Fo. "Note on Zola and Galdós: 1883-1887." Revista Canadiense de Estudios Hispánicos 32.3 (2008): 475-88.

CHAR NON-DEutsch, LOU. "Inhabited Space in Galdós's Tormento." Anales galdosianos 10 (1975): 35-43.

eoff, Sherman h. The Novels of Pérez Galdós: The Concept of Life as Dynamic

Process. Saint Louis: Washington UP, 1954.

Jagoe, Catherine. Ambiguous Angels: Gender in the Novels of Galdós. London: U of California P, 1994.

m Kinney, collin. Mapping the Social Body: Urbanisation, the Gaze, and the Novels of Galdós. Chapel Hill: U of North Carolina P, 2010.

M O N TES In OS, J OSÉ F. Galdós. 3 vols. Madrid: Castalia, 1968-1973, 1969.

PÉRE Z GALDós, BEn ITo. Lo prohibido. Ed. James Whiston. Madrid: Cátedra, 2001.

—. Tormento. Ed. Francisco Caudet. Madrid: Akal, 2002.

—. Tormento. Eds. Teresa Barjau and Joaquim Parellada. Barcelona: Crítica, 2007. RiB B AN S, GEOFFREY. “'Amparando/Desamparando a Amparo:' Some reflections on

El doctor Centeno and Tormento." Revista Canadiense de Estudios Hispánicos

17.3 (1993): 495-524.

RODGERS, EA m Onn. From Enlightenment to Realism. The Novels of Galdós 1870-1887.

Dublin: no pub., 1987.

RODRíguez, RODNEY T. “The Reader's Role in Tormento: A Reconstruction of the

Amparo- Pedro Polo Affair." Anales galdosianos 24 (1989): 69-78.

SCAN LON, GERALDINE. La polémica feminista en la España contemporánea 1868-

1974. Madrid: Akal, 1986.

SCHNEPF, MiCHAEL A. “The manuscript of Galdós's Tormento." Anales galdosianos

26 (1991): 43-49. 
UREY, DiANE F. "Repetition, Discontinuity and Silence in Galdós's Tormento." Anales galdosianos 20 (1985): 47-62.

wo o D, GaRe th. "Galdós, Shakespeare, and What to Make of Tormento." Modern Language Review 109.2 (2014): 392-416

WRIGHT, CHAD C. "'La eterna mascarada hispanomatritense': Clothing and Society in Tormento." Anales galdosianos 20 (1985): 25-35. 